Bijdragen tot de Dierkunde, 54 (2): 169-177-1984

\title{
HARMONICS IN COURTSHIP SOUNDS OF FOUR CARIBBEAN REEF FISH SPECIES OF THE GENUS EUPOMACENTRUS (POMACENTRIDAE)
}

\author{
by
}

\author{
HELMUT ALBRECHT \\ Department of Animal Behaviour, University of Amsterdam, The Netherlands
}

\begin{abstract}
SUMMARY
Four species of sympatric damselfishes (Eupomacentrus, Pomacentridae) produce and apparently use sounds in their courtship behaviour. Up to now, time structure elements were considered the key parameters in species recognition. Audible differences between the species, that can be ascribed to frequency characteristics of these sounds, are described here for the first time. It was found that both classes of parameters, i.e. of time structure and of frequency, can equally be responsible for species specificity within one locality. In other localities, different parameters (e.g. optical signals) or different combinations of different modalities could lead to the same result.
\end{abstract}

\section{ZUSAMMENFASSUNG}

Vier sympatrische Riffbarscharten (Eupomacentrus, Pomacentridae), die Balzlaute zur Arterkennung benutzen können, unterscheiden sich in mehreren Lautmerkmalen voneinander. Neben schon länger bekannten Merkmalen, die die Zeitstruktur eines Balzlautes betreffen, werden Merkmale hinsichtlich von Frequenzeigenschaften erstmals beschrieben. Offenbar werden verschiedene dieser Eigenschaften oder aber unterschiedliche Kombinationen davon in verschiedenen Teilen ihres Verbreitungsgebietes benutzt. Ihr relativer Einfluss nebst möglichen anderen (z.B. optischen) Signaleffekten bedarf weiterer Untersuchungen.

\section{INTRODUCTION}

Fishermen, in many parts of the world, have been able to recognize fish by the sounds they make, probably since ancient times. This art has long defied a scientific analysis. After initial publications by Sørensen $(1884,1894)$, research in this field accelerated in the decades after the 2nd world war (Marshall, 1962; Winn, 1964; Schneider, 1967; Tavolga, 1971; Fine et al., 1977; Myrberg, 1981; Hawkins \& Myrberg, 1983).
Among the many sound-producing fish species, discussed in the above-mentioned reviews, are members of the ubiquitous, tropical reef fish family Pomacentridae. Moulton (1958) was the first to describe some of their sounds and the context in which they occur, namely as a signal in territory defence and in reproduction. The present paper is an extension of this and many subsequent studies on pomacentrids as discussed by Albrecht (1981).

Since several sympatric Eupomacentrus species are similar in size, colouration and courtship movements, one may hypothesize that sounds play a decisive role in species recognition during courtship behaviour. They are prominent elements in their courtship indeed (Moulton, 1958; Myrberg, 1971, 1972 a-c; Myrberg \& Spires, 1972; Albrecht, 1981).

Sounds may either be produced by sudden body movements, or they are the product of vibrations of the swimbladder. However, most sounds are produced by stridulation.

\section{Stridulatory sounds}

Stridulatory sounds in fishes are basically percussive and any messages are the elaboration of pulses. They are produced by friction between neighbouring parts of the skeleton. One of the commonest types of friction is that between the pharyngeal teeth. The upper pharyngeal bones (upper parts of the gill arches) bear teeth that bite against the lower pharyngeals, a pair of bones derived from the fifth gill arches and situated on the floor of the "throat" just behind the gills. They have a rasping, scraping or scratching character. Stridulatory sounds are 
usually nonharmonic in structure, i.e. they do not resolve in a spectogram into a series of horizontal bars at harmonic intervals, as they contain many harmonically unrelated frequencies (Tavolga, 1971). The range in spread of frequency may be extremely wide, often from 50 to $4800 \mathrm{~Hz}$, and as a general rule the maximum energy is located higher in the spectrum than in the case of air bladder sounds (M. P. Fish, 1954). Many stridulatory sounds are primarily an inevitable byproduct of feeding. Some species stridulate in connection with alarm, territoriality and courtship (Tavolga, 1971).

\section{Swimbladder sounds}

Swimbladder sounds are usually low pitched, guttural, vibrant and drum-like (Marshall, 1962). Generally, they are recognizable by their harmonic structure with several harmonics above the fundamental frequency in the 100-300 $\mathrm{Hz}$ range (Tavolga, 1971).

Different mechanisms, which cause the swimbladder to resonate, have been described. Special muscles, often together with various bony structures which act as springs, throw the swimbladder into vibrations which produce sound (Sørensen, 1884, 1894).

In one, particularly common, mechanism friction between the pharyngeal teeth causes the swimbladder to resonate (Tavolga, 1971). This makes the distinction between stridulatory sounds and swimbladder sounds not clear cut. Stridulatory mechanisms, after all, can cause the swimbladder to resonate to some extent even without a specific connection. Various mechanisms of this sort have been described or inferred for members of many fish families (Marshall, 1962; Tavolga, 1971). Of particular interest here are the following findings:

Burkenroad (1930) describes the sound and the sound-producing mechanism of the grunt (Haemulon plumieri, Pomadasyidae) in some detail. He notes that if the swimbladder was deflated, the character of the sound produced by "gnashing of the teeth" became dry and lost its grunt-like quality, i.e. its harmonic content.
A faint grating sound was produced instead of the normal sound which is a loud, deep rasping kind of croak (Burkenroad, 1931; M. P. Fish, 1954).

The toad fish (Opsanus tau, Batrachoididae), is probably the best-studied species from the point of view of sonic communication (J. F. Fish, 1972; Fine et al., 1977). It produces a tone with harmonics and led Harris (1964) to the conclusion that the swimbladder has the elastic and resonant qualities of an underwater sound producer. Tavolga \& Wodinski (1963) constructed an underwater loudspeaker along the physical principles of a toad fish swimbladder and found it to be quite efficient in the $100-2000 \mathrm{~Hz}$ range. In acoustic and electronic terms, the swimbladder is an impedancematching device analogous to the large surface cone of a high fidelity loudspeaker (Tavolga, 1971).

The fact that size and form of the swimbladder are important correlates of species-specific sound has been known since the studies on drumfish (Scienidae) (Tower, 1908), which have been largely extended by Tavolga (1958; 1960 a \& b). Likewise, Marshall (1962) notes that the individual expression of swimbladder form must surely be related to the acoustic expression and that differences in sound are related to divergences in swimbladder structure.

One result of Fish \& Mowbray (1970) is in line with the above statement and, as it was obtained with pomacentrids, it leads to the questions to be considered here. According to these authors, the sound-producing mechanism of various pomacentrid fishes lies in the swimbladder and in others additionally in the pharyngeal teeth. Eupomacentrus dorsopunicans, for instance, uses the swimbladder alone for sound production, pharyngeal tooth participation is not apparent, whereas Eupomacentrus leucostictus uses both mechanisms. This could explain why Albrecht (1981) found differences in sound quality between several pomacentrid species, including the two mentioned above. These audible differences could only be characterized 
by the terms harsh, soft, mellow, bright, etc. They can be explained solely by differences in harmonic structure.

Fish species, that can be discriminated by pitch and quality of their sounds, i.e. their fundamental frequency and harmonic content, have received little attention, however. The role of frequency in coding fish sounds is poorly understood and there is no proof of relevance of harmonics to meaning in a fish signal (Fine et al., 1977). Winn (1964) differentiates the various aspects of a sound signal into (1) amplitude, (2) duration, (3) repetition rate, (4) number of pulses and (5) frequency. The present paper is concerned with point 5 , whereas most results so far pertain to rhythm and/or time structure of fish sounds, i.e. the abovementioned points 2-4. It is suggested that four species of Eupomacentrus are examples of fishes producing and possibly using harmonics in their courtship behaviour. ${ }^{*}$

The present study deals with properties of sounds which are important for species recognition in closely related sympatric fish species. The relatively few pertinent studies in this systematic group all concentrate on the time structure of sounds.

Agonistic sounds of several sympatric triggerfishes (Balistidae) vary in duration and pulsing (Salmon et al., 1968). Playback experiments in six sympatric species of sunfish (Centrarchidae) show that species-specific calls are differently reacted upon by the species in question. The results warrant the assumption that call duration and pulsing play a role in their speciesrecognition system (Gerald, 1971). The same applies to locally restricted populations of several species of damselfishes (Pomacentridae)

\footnotetext{
* The courtship sounds of Eupomacentrus spec. have often been called "chirp" (e.g. Myrberg et al., 1978). This is a verbal transcription of a stridulatory sound with its frequency range extending continuously throughout its range, i.e. having no harmonic structure. Difficult as it is finding onomatopoetic descriptions of sounds, this term was sufficient as long as attention was focused on the time structure of this sound. However, it does not refer to its tonal quality which it has due to the participating role of the swimbladder.
}

(Spanier, in Fine et al., 1977; Myrberg et al., 1978; Spanier, 1979). Males of at least four species produce extremely similar sounds in the same context of their very similar and probably homologous courtship (Albrecht, 1969). They have a common reproductive season and often court in visual and acoustical contact with congeners. Investigations of the time structure of these sounds, interesting as they are, are inconclusive as to the key factor(s) for species recognition. Unfortunately, the similarity of the frequency spectra of the species in question precluded their further analysis (Albrecht, 1981).

Frequency modulation within a call, which is common in birds and mammals, is rare or nonexistent in fishes (Fine et al., 1977), the only exception so far being the results of Caldwell \& Caldwell (1967) with the pinfish, Lagodon rhomboides (Sparidae), and of Tavolga (1958, 1960 a \& b) with the toadfish, Opsanus tau.

Besides the biological problem of species recognition by sound, there is also a technical problem. Even if sound recordings are carefully balanced in order to prevent the development of artificial harmonics, and if the sounds are sufficiently distant from the hydrophone to exclude the near field effect (Tavolga, 1965, Schneider, 1967), some spectrum analyzers tend to indicate an artificial harmonic structure of sounds when they consist of rapidly repeated pulses (Hawkins \& Myrberg, 1983). An artificial harmonic structure precludes frequency analysis on such a fine level. With the present instrumentation this disturbing factor could be excluded.

\section{MATERIALS AND METHODS}

Comparable courtship sounds of four sympatric species of damselfishes were recorded in the reef area in widely different parts of the Caribbean, viz. Bimini (Bahamas) in 1967-1968, and Curaçao (Netherlands Antilles) in 1975. The species investigated were: Eupomacentrus leucostictus (Müller \& Troschel, 1848), E. planifrons (Cuvier, 1830), $E$. partitus (Poey, 1867), and E. dorsopunicans (Poey, 1861).

The following recording equipment was used: tape recorders Uher (1000 Pilot, 4000 report) and Nagra (IV $\mathrm{SJ}$ ); hydrophone (CIC US Navy). The sounds were processed using a frequency analyzer Nicolet type Ubiquitos UA500A. This instrument was adjusted for a frequency 


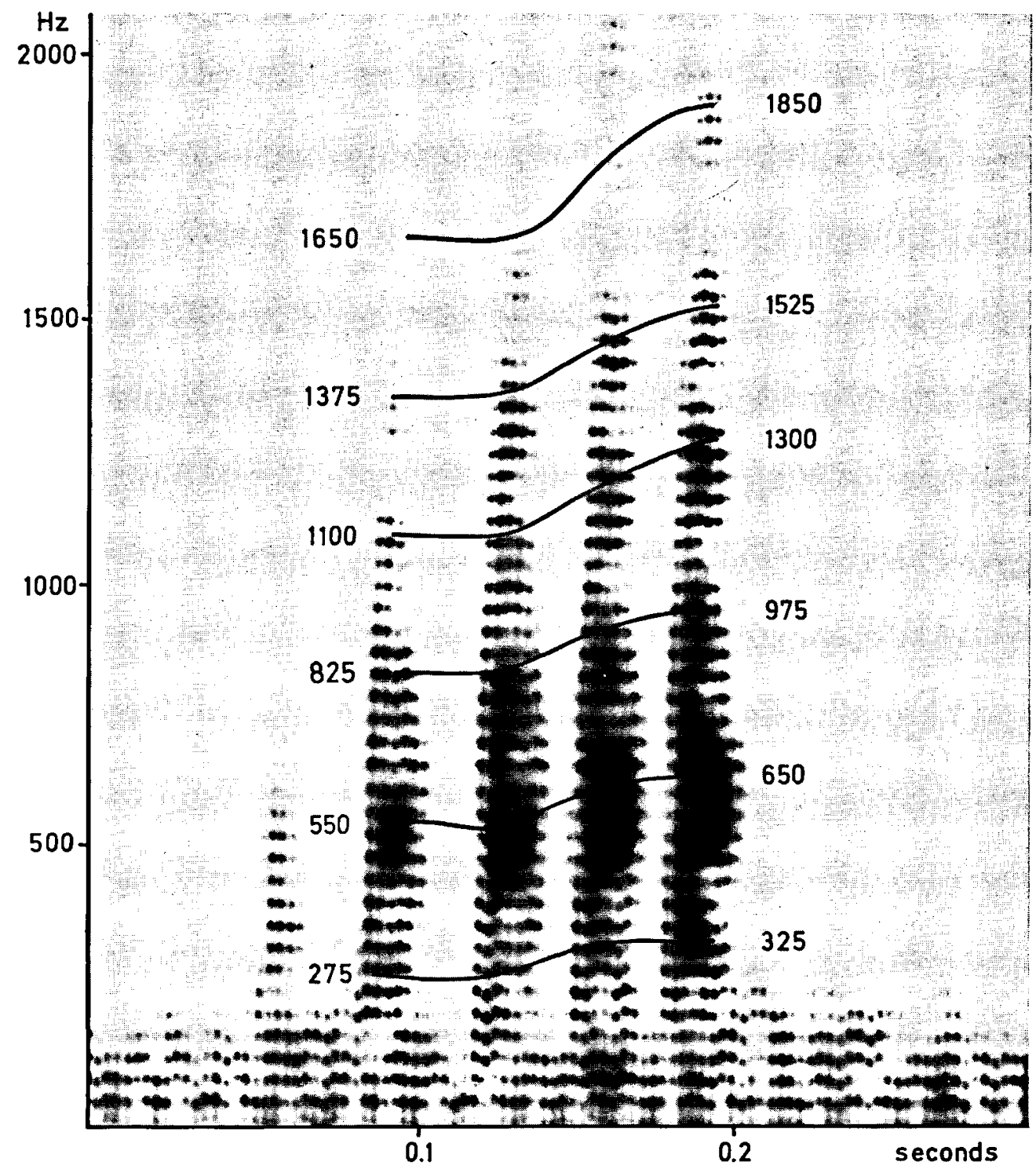

Fig. 1. Example of a frequency modulated call (E. leucostictus, Bimini) with four elements. The curves clarify the harmonic structure. The first element has its basic frequency at $275 \mathrm{~Hz}$ and the fourth element at $325 \mathrm{~Hz}$. The second harmonic $(550-650 \mathrm{~Hz})$ is predominant.

range up to $1000 \mathrm{~Hz}$; with the tape recorder Nagra IV SJ running at half speed, it analyzed up to $2000 \mathrm{~Hz}$. The Nicolet analyzes the frequency structure of a sound every $50 \mathrm{msec}$. In order to make this structure more clearly visible, it was terminated for $1000 \mathrm{~Hz}$. Termination in this case implies that a frequency analysis was performed every $5 \mathrm{msec}$ instead, but with each analysis adding only $10 \%$ new information (Schnitzler, pers.comm.).

In this way a total of 1070 sounds were described: E. leucostictus, Curaçao, $N=76, E$. leucostictus, Bimini, $N=175 ; E$. planifrons, Curaçao, $N=175, E$. planifrons,
Bimini, $N=111 ; E$. partitus, Curaçao, $N=105, E$. partitus, Bimini, $N=70 ; E$. dorsopunicans, Curaçao $N=131, E$. dorsopunicans, Bimini, $N=97$.** $^{*}$

** Recently, A. R. Emery \& G. R. Allen (Rec. West. Aust. Mus., 8 (2): 199-206, 1980) proposed to consider Eupomacentrus a junior synonym of Stegastes. For the purpose of this ethological paper, I prefer to retain the name Eupomacentrus, which is still better known in ethological and ecological studies. 
TABLE I

Differences between number of harmonic vs. nonharmonic elements ( $t$-test) for all four species and both localities $(\mathrm{Bi}=\mathrm{Bimini}, \mathrm{Cu}=\mathrm{Curaçao})$ together; 4131 elements were taken from 1070 sounds.

\begin{tabular}{|c|c|c|c|c|c|c|c|c|c|}
\hline \multirow[b]{2}{*}{ harmonic } & \multicolumn{2}{|c|}{ E. leucostictus } & \multicolumn{2}{|c|}{ E. partitus } & \multicolumn{2}{|c|}{ E. planifrons } & \multicolumn{2}{|c|}{ E. dorsopunicans } & \multirow{2}{*}{$\frac{\text { Total }}{3356}$} \\
\hline & 424 & 737 & 275 & 202 & 444 & 362 & 476 & 436 & \\
\hline not harmonic & 39 & 51 & 30 & 7 & 189 & 46 & 246 & 167 & 775 \\
\hline total & 463 & $\begin{array}{l}788 \\
\mathrm{Bi}\end{array}$ & 305 & $\begin{array}{l}209 \\
\mathrm{Bi}\end{array}$ & 633 & 408 & 722 & $\begin{array}{l}603 \\
\mathrm{Bi}\end{array}$ & 4131 \\
\hline
\end{tabular}

\section{RESULTS}

Each comparable courtship sound consists of a various number of pulses or elements (Albrecht, 1981). Most of these elements show a harmonic structure. Three properties were considered for analysis: (1) harmonic content, (2) basic frequency, (3) modulation (see fig. 1).

\section{(1) Harmonic content}

Courtship sounds of all species contain significantly more harmonic elements than elements for which no harmonic structure is discernible (table I). The first elements within a given sound are always weaker and show less harmonics than subsequent ones. The second harmonic frequency within an element is usual- ly the dominant one. As to harmonic content, no possible local or species differences have been taken into consideration. This is done, however, for the following points.

\section{(2) Basic frequency}

The mean basic frequencies are shown in fig. 2 . With regard to this property, significant differences can be seen between all four pomacentrid fish species from Bimini. In Curaçao only half of the possible combinations differ from each other. In other words, the same sympatric groupings of species, but from different localities, show species-specific differences to a great extent (fig. 3). This is what the hypothesis predicts.

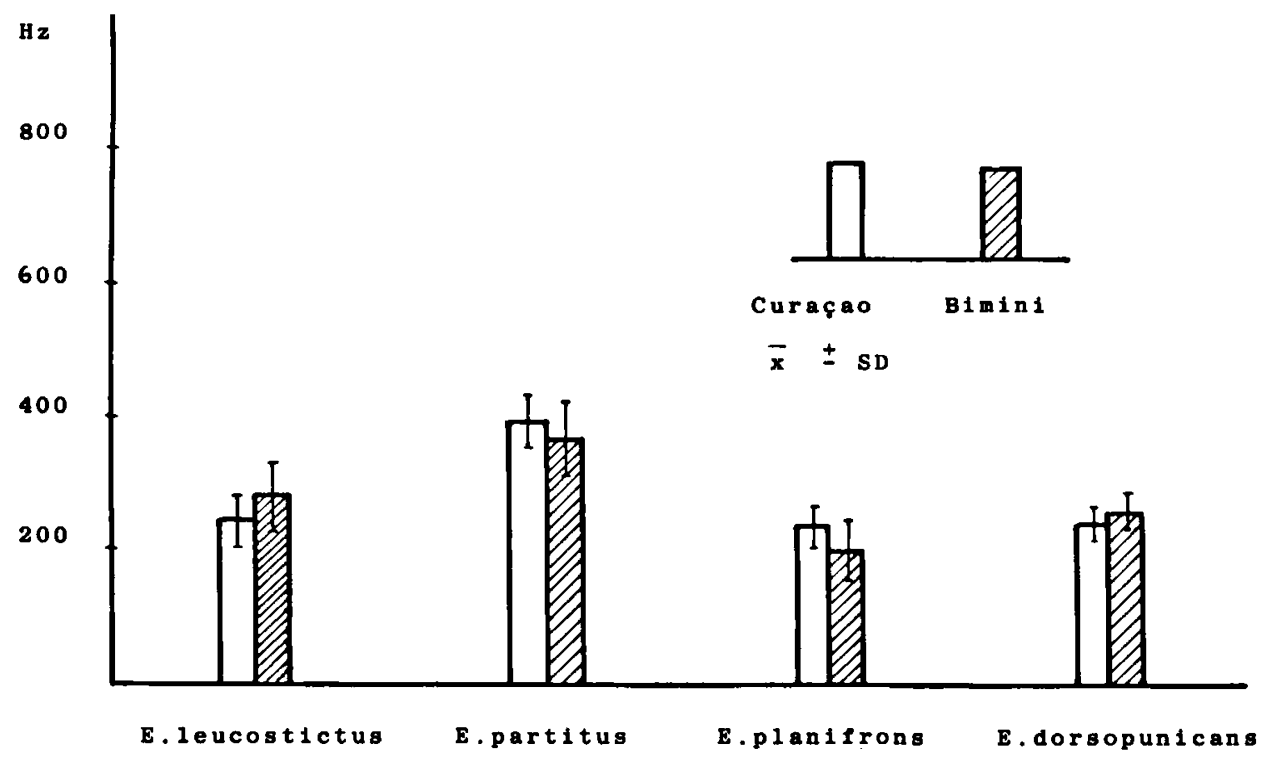

Fig. 2. Mean basic frequency for Bimini (analysis of variance, unequal cell frequencies, $F$ $(3,483)=293, \alpha<0.001$ ) and Curaçao (unequal cell frequencies, $F(3,449)=453, \alpha<0.001$ ). 


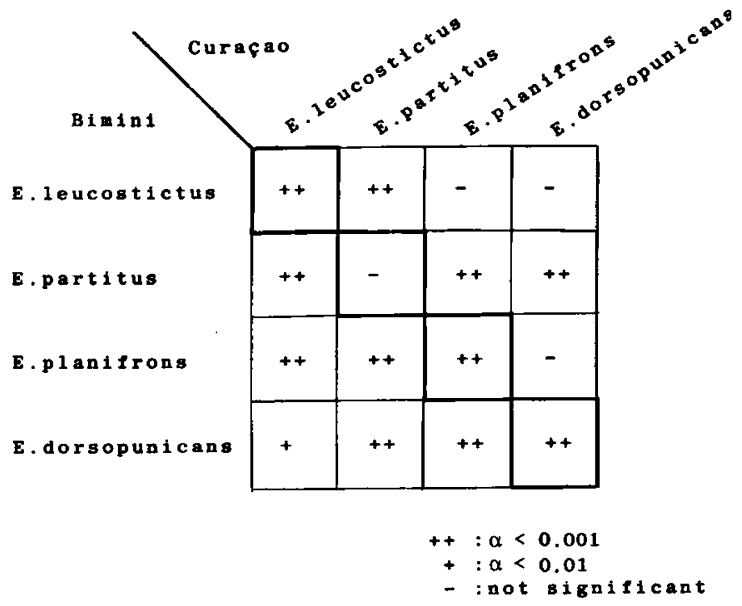

Fig. 3. Differences in mean basic frequency of courtship calls between four pomacentrid fish species from Curaçao and Bimini. Above the diagonal line, results are shown for Curaçao, below the diagonal line for Bimini. Along the diagonal line intraspecific differences between each of the four species but from different localities are shown $\left(\chi^{2}\right.$ test).

There are also intraspecific differences for three species between the two localities, viz. local differences within species (fig. 3). Considering the long distance between Bimini and Curaçao $(1800 \mathrm{~km}$, and probably much more as these fishes have distributed themselves over the Caribbean) this is not surprising.

\section{(3) Modulation}

No procedure has been developed to quantify the degree of modulation other than going up or going down. All that can be said so far is, that many sounds show frequency modulation. Its occurrence shows interspecific differences both within the Curaçao and within the Bimini species group. Again, as with regard to basic frequency, local intraspecific differences exist as well (fig. 4).

The results of points (2) and (3) combined show that in most cases the frequency parameters modulation and basic frequency point in the same direction of species specificity. In some cases it is only one or the other parameter that characterizes the courtship sounds of the four species in question; only one

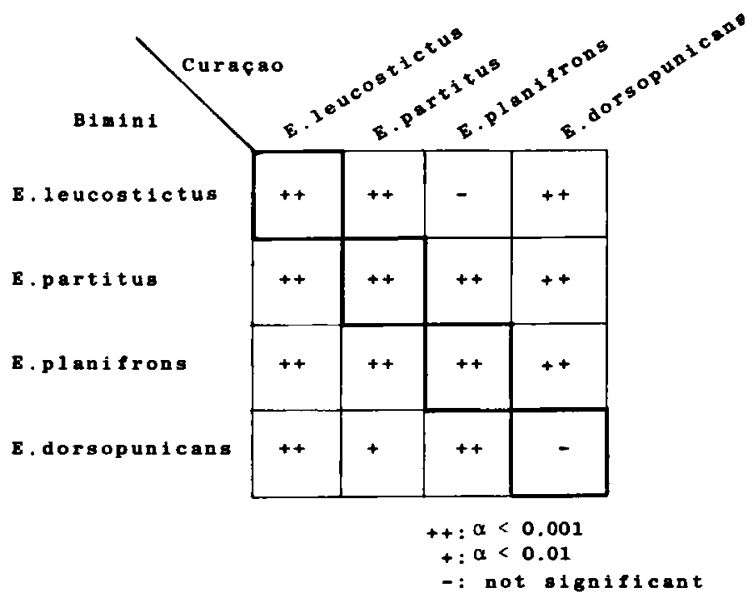

Fig. 4. Differences in modulation characteristics of courtship calls of four pomacentrid fish species from Curaçao and from Bimini. Above the diagonal line, each comparison of two species for Curaçao is shown and below the line for Bimini. Along the diagonal line intraspecific differences of each of the four species but from different localities are shown ( $\chi^{2}$ test).

species pair in one of the localities ( $E$. planifrons vs. E. leucosticus in Curaçao) shows no differences with regard to both parameters.

For all four species, from Bimini as well as from Curaçao, call series are found containing the same calls with regard to all parameters investigated. It is almost certain that they reflect individual characteristics of a particular fish. This would mean that within, a confined breeding colony individual fish are able to express and, possibly, recognize themselves individually. This phenomenon, certainly, needs further investigation.

\section{DISGUSSION}

In the search for the key factor within the sound communication system of Eupomacentrus species, various experiments have been conducted (Spanier, in Fine et al., 1977; Myrberg et al., 1978; Spanier, 1979). They emphasize that an important parameter for species recognition of Eupomacentrus calls is the off-time or interval between the elements of a sound, rather than 

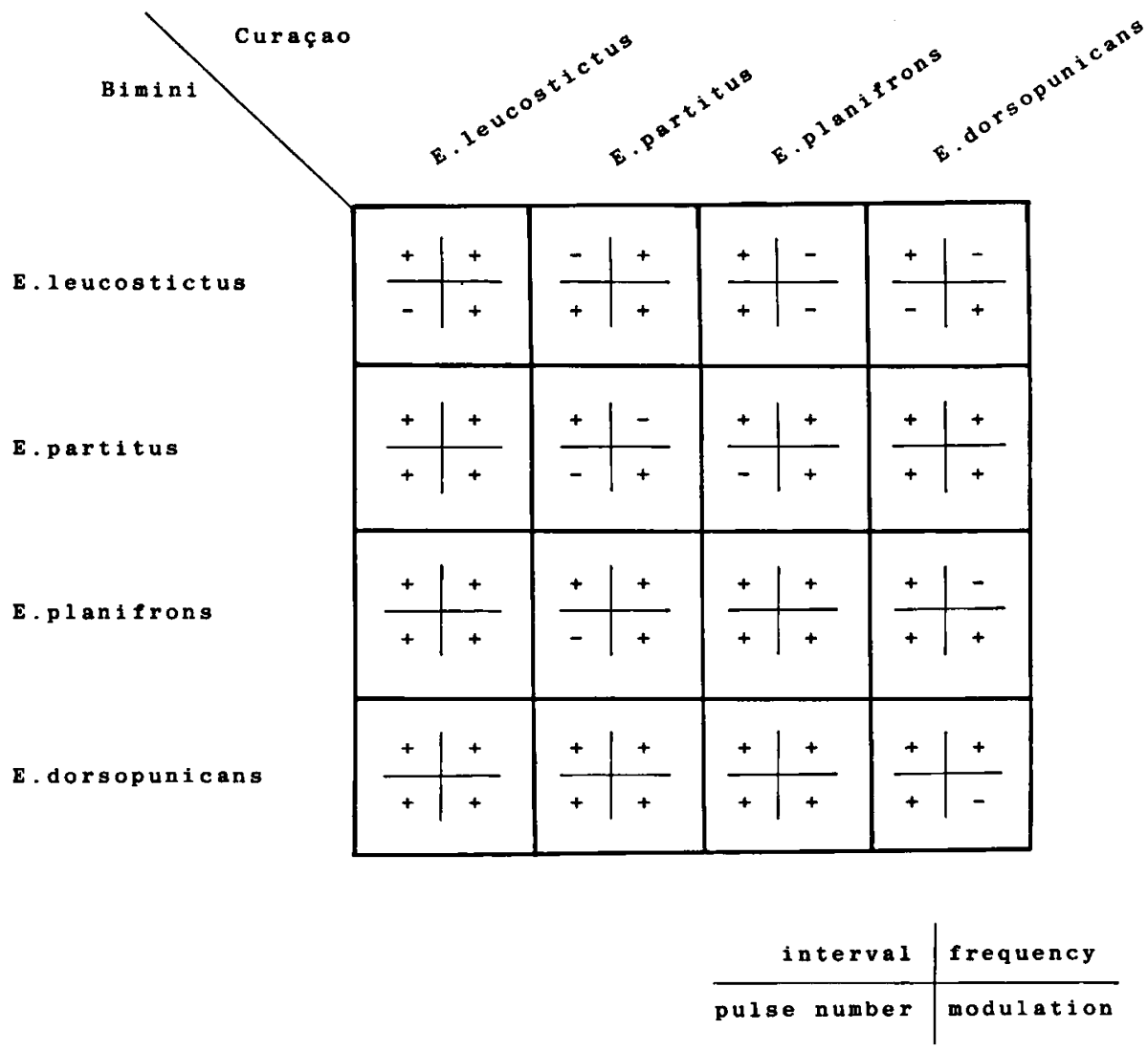

Fig. 5. Four courtship sound parameters: pulse interval and pulse number (Albrecht, 1981), basic frequency and modulation (present paper) combined. For all four species local differences exist for at least two of the parameters (diagonal). Interspecific differences for both localities (Bimini, Curaçao) depend on various combinations of the four parameters (significant differences designed as + ).

pulse duration. Frequency was not tested. The strongest argument in support of this conclusion comes from one of Spanier's experiments, in which reaction to sounds of conspecifics and artificially altered sounds of other species were compared. The modification consisted of lengthening the pulse interval within a sound (i.e. the off-time) so that it equalled the pulse interval of conspecifics:

$E$. dorsopunicans were confronted with sounds of conspecifics, with sounds of $E$. leucostictus and with internally altered sounds of $E$. leucostictus. The result was clear: $E$. dorsopunicans could not differentiate between sounds of conspecifics and the modified sounds. The conclusion, that the interval length between the elements of a court- ship sound was a key factor, seemed warranted. However, a time structure analysis of the pertinent sound, but from different parts of the Caribbean, showed that interval length was not species specific throughout the range of the fish species in question. In experiments with the same species in Curaçao, no reaction to sounds from conspecifics was found from either the same or other localities (Albrecht, 1981). Time structure then could not be species specific throughout its range and was not, apparently, used at all as a parameter. As the playback instrumentation was only reliable with regard to time structure characteristics and, possibly, not with regard to frequency characteristics, no conclusion could be made with regard to the lat- 
ter. All that could be said is, that $E$. dorsopunicans in Curaçao uses other parameters for species recognition than in the Florida Keys (Albrecht, 1981).

Species recognition in fish can be very complex (not to mention the many studies on amphibians and birds) (Hopkins, 1980, 1981, 1983; Hopkins \& Bass, 1981).

A combination of the results of time structure analysis (Albrecht, 1981) and of the present frequency analysis (figs. 5 and 6) leads to the conclusion that none of the four parameters in particular is a prime candidate for a key code within the communication system of the species in question, but different combinations in different localities could well be of importance as compared to other cues, which have yet to be investigated. The relative importance of various parameters will have to be established before we can say more about the modes and codes of these puzzling animals. For a start with pomacentrids, playback experiments should be conducted considering more parameters than those used up to now, and geographical variations of as many parameters as possible in the species concerned should be carefully mapped.

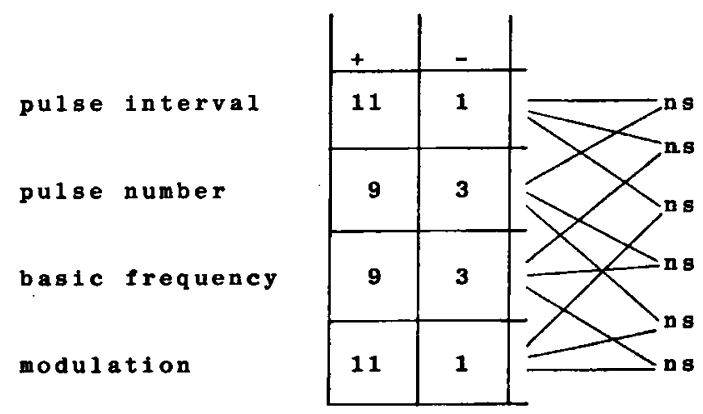

Fig. 6. None of the four parameters can be considered as a prime candidate for serving a key function in a sound communication system of the four pomacentrid fish species (Fisher exact probability test, two-tailed; ns = not significant at $5 \%$ level).

\section{ACKNOWLEDGEMENTS}

Special thanks are due to Prof. Dr. J. H. Stock, University of Amsterdam, for his continuing interest and support of the present study. Prof. Dr. H. Schitzler kindly offered advice in his bioacoustical laboratory, University of Tüb- ingen, especially with regard to the spectrum analyzer (Nicolet, type UA 500 A Ubiquitos, support of Deutsche Forschungsgemeinschaft).

For their hospitality I thank also Prof. Dr. R. Apfelbach, University of Tübingen, Dr. R. Kaufmann, Instituto Colombo-Aleman, Punta de Betín, Santa Marta, Colombia, Dr. I. Kristensen, Caribbean Marine Biological Institute (CARMABI), Curaçao, Netherlands Antilles, and Prof. Dr. A. Myrberg, Rosenstiel School of Marine and Atmospheric Science, University of Florida, U.S.A.

J. P. Abell, University of Amsterdam, helped with the statistical analysis. The manuscript was read and criticized by P. Cornelissen, J. Bouwer, Dr. J. P. C. de Bruin and Drs. N. de Jong. The figures were drawn by P. Duyst and the final version was typed by Mrs. A. Brederoo.

\section{REFERENCES}

Albrecht, H., 1969. Behaviour of four species of Atlantic damselfishes from Colombia, South America (Abudefduf saxatilis, A. taurus, Chromis multilineata, C. cyanea; Pisces, Pomacentridae). Z. Tierpsychol., 26: 662-676.

- 1 1981. Aspects of sound communication in some Caribbean reef fishes (Eupomacentrus spec., Pisces, Pomacentridae). Bijdr. Dierk., 51 (1): 70-80.

Burkenroad, M. D., 1930. Sound production in the Haemulidae. Copeia, 1930: 17-18.

- , 1931. Notes on the sound producing fishes of Louisiana. Copeia, 1931: 20-28.

Caldwell, D. K. \& M. C. Caldwell, 1967. Underwater sounds associated with aggressive behavior in defence of territory by the pinfish, Lagodon rhomboides. Bull. Sth. Calif. Acad. Sci., 66: 69-75.

Fine, M. L., H. E. Winn \& B. L. Olla, 1977. Communication in fishes. In: T. A. Sebeok ed., How animals communicate: 472-518 (Indiana University Press, Bloomington, London).

Fish, J. F., 1972. The effect of sound playback on the toadfish. In: H. E. WinN \& B. L. Olla eds., Behavior of marine animals, 2: 386-434 (Plenum Press, New York).

Fish, M. P., 1954. The character and significance of sound production among fishes of the western North Atlantic. Bull. Bingham oceanogr. Coll., 14: 1-109.

Fish, M. P. \& W. H. Mowbray, 1970. Sounds of western North Atlantic fishes: 1-205 (Johns Hopkins Press, Baltimore).

Gerald, J. W., 1971. Sound production during courtship in six species of sunfish (Centrarchidae). Evolution, 25: 75-87.

Harris, G. G., 1964. Considerations on the physics of sound production by fishes. In: W. N. TAvolga ed., Marine bioacoustics: 233-247 (Pergamon Press, Oxford). 
Hawkins, A. D. \& A. A. Myrberg, 1983. Hearing and sound communication under water. In: B. Lewis ed., Bioacoustics, a comparative approach: 347-405 (Academic Press, London).

Hopkins, C. D., 1980. Evolution of electric communication channels of mormyrids. Behav. Ecol. Sociobiol., 7: 1-13.

- , 1981. On the diversity of electric signals in a community of mormyrid electric fish in West Africa. Am. Zool., 21: 211-222.

- , 1983. Neuroethology of species recognition in electroreception. In: J. P. Ewert, R. R. Capranica \& D. J. InGLE eds., Advances in vertebrate neuroethology: 871-881 (Plenum Press, New York).

Hopkins, C. D. A. H. Bass, 1981. Temporal coding of species recognition in an electric fish. Science, 212: $85-87$.

Marshall, N. B., 1962. The biology of sound producing fishes. Symp. zool. Soc. London, 7: 45-60.

Moulton, J. M., 1958. The acoustical behavior of some fishes in the Bimini area. Biol. Bull., 114: 357-374.

Myrberg, A. A., 1971. Hearing and allied senses in fishes. Final Report National Science Foundation: $1-52$.

- - 1972a. Ethology of the Bicolor Damselfish, Eupomacentrus partitus (Pisces; Pomacentridae): a comparative analysis of laboratory and field behavior. Anim. Behav. Monogr., 5: 197-283.

- - 1972b. Social dominance and territoriality in the Bicolor Damselfish Eupomacentrus partitus (Poey) (Pisces; Pomacentridae). Behaviour, 41: 207-231.

- , 1972c. Using sound to influence the behaviour of free ranging marine animals. In: H. E. WINN B. L. Olla eds., Behavior of marine animals, 2: 435-468 (Plenum Press, New York).

- , 1981. Sound communication and interception in fishes. In: W. N. Tavolga, A. N. Popper \& R. R. FAY eds., Hearing and sound communication in fishes: 395-426 (Springer, New York).

Myrberg, A. A. \& J. Y. Spires, 1972. Sound discrimination by the bicolor damselfish, Eupomacentrus partitus. J. exp. Biol., 57: 727-735.

Myrberg, A. A., E. Spanier \& J. S. HA, 1978. Temporal patterning in acoustical communication. In: E. S. ReEse \& F. J. Lighter eds., Contrasts in behavior: 137-179 (John Wiley \& Sons, New York).
Salmon, M., H. E. Winn \& N. Sorgente, 1968. Sound production and associated behavior in triggerfish. Pacif. Sci., 22: 11-20.

Schneider, H., 1967. Morphology and physiology of sound producing mechanisms in teleost fishes. In: W. N. Tavolga ed., Marine bioacoustics, 2: 135158 (Pergamon Press, New York).

Sørensen, W., 1884. Om lydorganer hos fiske: En physiologisk og comparativ-anatomisk undersøgelse: i-viii, 1-245 (Ph.D. thesis, University of Copenhagen; Thåning \& Appels Press, Kopenhagen).

- - 1894. Are the extrinsic muscles of the airbladder in some Siluroidea and the "elastic spring" apparatus of others subordinate to the voluntary production of sound? J. Anat. Physiol. Lond., 9: 109-139, 205-229, 399-423, 518-552.

Spanier, E., 1979. Aspects of species recognition by sound in four species of damselfishes, genus Eupomacentrus (Pisces; Pomacentridae). Z. Tierpsychol., 51: 301-316.

Tavolga, W. N., 1958. Underwatersounds produced by two species of toad fish, Opsanus tau and Opsanus beta. Bull. mar. Sci. Gulf Carib., 8: 278284.

- 1960 a. Foghorn sounds beneath the sea. Nat. Hist. N.Y., 69 (3): 44.

- $1960 \mathrm{~b}$. Sound production and underwater communication in fishes. In: W. E. LANYON \& W. N. Tavolga eds., Animal sounds and communication. Publs. Amer. Inst. biol. Sci., 7: 93-136.

- - 1965. Review of marine bioacoustics. Tech. Rep. U.S. Naval Training Device Center, Port Washington, New York, 1212 (1).

- , 1971. Sound production and detection. In: W. S. Hoar \& D. J. Randall eds., Fish physiology, 5: 135-205 (Academic Press, New York).

Tavolga, W. N. J. Wodinski, 1963. Auditory capacities in fishes. Pure tone thresholds in nine species of marine teleosts. Bull. Amer. Mus. nat. Hist., 126: 179-239.

Tower, R. W., 1908. The production of sound in the drumfishes, the sea robin and the toadfish. Ann. N.Y. Acad. Sci., 18: 149-180.

Winn, H. E., 1964. The biological significance of fish sounds. In: W. N. TAvolga ed., Marine bioacoustics: 213-231 (Pergamon Press, New York). 